\title{
The Most Useful Method to Evaluate the Volume Status of Critical Patients in The Emergency and Intensive Care Units: Point of Care Ultrasound
}

\author{
Acil Servis ve Yoğun Bakım Ünitelerindeki Kritik Hastaların Volüm \\ Durumunu Değerlendirmede En Kullanışlı Yöntem: Yatak Başı Ultrasonu
}

\author{
Deltem İnce', oMetin Ocak' \\ 'Samsun Gazi State Hospital, Emergency Clinic, Samsun, Turkey
}

\begin{abstract}
Background: Accurate and rapid assessment of intravascular volume status of the patients in emergency services and intensive care units at diagnosis, treatment and follow-up stages is crucial yet rather difficult. The purpose of hemodynamic monitoring is to determine cardiovascular insufficiency and to provide the most suitable treatment for unstable patients in critical condition.

Aim: The study aims to compare vena cava inferior diameter, vena cava inferior- collapsibility index (for spontaneously breathing patients) and vena cava inferior- distensibility index (for patients breathing on mechanical ventilation support) measurement by ultrasonography to central venous pressure measurement by placing invasive catheter for assessment of the intravascular volume status and making an accurate volume replacement in emergency service and intensive care units and to determine the correlation between them.

Material and Method: The study was carried out prospectively on the patients above the age of 18 who applied to the emergency service clinic between the dates of 01.06.2014 and 01.04.2015 or who stayed in the emergency intensive care unit between these dates. Measurements were taken from vena cava inferior in both the inspirium and expirium phases by using $\mathrm{M}$ mode and they were recorded in millimeter. Simultaneous central venous pressure measurements were performed on the patients by using manometric devices and the results were recorded in $\mathrm{cm} \mathrm{H}_{2} \mathrm{O}$.

Results: $43.3 \%$ of the patients were female ( $n: 26)$ and $56.7 \%$ were male (n: 34$)$, and the mean age is $70.58 \pm 14.86$. The study found high degree of positive correlation between central venous pressure and vena cava inferior diameters and high degree of negative correlation between vena cava inferior-collapsibility index. The study also found that there is a high degree of negative correlation between vena cava inferior- distensibility index and central venous pressure in patients receiving mechanical ventilatory support.

Conclusion: Measurement of respiratory variation in vena cava inferior diameter by using ultrasonography is a quick, reliable, easily applicable, costefficient and non-invasive method in critical patients receiving mechanical ventilatory support or have spontaneous respiration in emergency services and intensive care units and it can be useful in assessing the volume status and estimating central venous pressure.
\end{abstract}

Keywords: Central venous pressure, vena cava inferior, ultrasonography, volume status, collapsibility

\section{Öz}

Giriş: Acil servis ve yoğun bakımdaki hastaların; tanı, tedavi ve takibinde intravasküler volüm durumunun, doğru ve hızlı şekilde tespiti oldukça önemli ve bir o kadar da zordur. Hemodinamik izlemin amacı kardiyovasküler yetmezliği belirlemek ve stabil olmayan kritik düzeydeki hastalara (septik şok, hipovolemi, kardiyojenik şok v.b.) en uygun tedaviyi sağlamaktır.

Amaç: Bu çalışmada amacımız; acil servis ve yoğun bakım ünitesinde, intravasküler volüm durumunu değerlendirmede ve doğru volüm replasmanına yönlenmede ultrasonografi ile vena cava inferior çapı, vena cava inferior - kollapsibilite indeksi (spontan solunumu olan hastalar için) ve vena cava inferior distensibilite indeksi (mekanik ventilasyon desteğinde soluyan hastalar için) ölçümünün invaziv kateter yerleştirilerek yapılan santral venöz basınç değeri ile karşılaştırııması ve arasındaki ilişkinin saptanmasıdır.

Gereç ve Yöntem: Bu çalışma acil tıp kliniğine 01.06.2014-01.04.2015 tarihleri arasında başvuran veya bu tarihler arasında acil yoğun bakım ünitesinde yatmakta olan, herhangi bir endikasyon ile santral venöz kateter takılan 18 yaş üstü hastalar üzerinde prospektif olarak yürütüldü. Vena cava inferiordan ultrasonografik M mod kullanılarak, hem inspiryum hem de ekspiryum fazında ölçümler alındı ve milimetre cinsinden kaydedildi. Hastalardan eş zamanlı santral venöz basınç ölçümü monometrik cihazlar ile yapıldı ve sonuçlar $\mathrm{cm}$ $\mathrm{H}_{2} \mathrm{O}$ cinsinden kayıt altına alındı.

Bulgular: Hastaların \%43.3'ü kadın (n:26), \%56.7'si erkek (n:34) olup, yaş ortalamaları $70.58 \pm 14.86$ yıl idi. Santral venöz basınç ile vena cava inferior çapları arasında pozitif yönde, vena cava inferior- kollapsibilite indeksi arasında negatif yönde yüksek derecede korelasyon tespit edildi. Çalışmamızda ayrıca mekanik ventilatör ile solunumu sağlanan hastalarda da vena cava inferiordistensibilite indeksi ve santral venöz basınç arasında negatif yönde yüksek derecede korelasyon olduğu saptandı.

Sonuç: Acil servis ve yoğun bakım ünitelerinde mekanik ventile ya da spontan solunuma sahip olan kritik hastalarda; hızl, güvenilir, kolay uygulanabilir, maliyeti düşük ve noninvaziv bir yöntem olan ultrasonografi ile vena cava inferior çapındaki respiratuar değişkenlik ölçümü; volüm durumunu değerlendirmede ve santral venöz basıncı tahmin etmede kullanılabilir.

Anahtar Kelimeler: Santral venöz basınç, vena cava inferior, ultrasonografi, volüm durumu, kollapsibilite 


\section{INTRODUCTION}

Accurate and rapid assessment of intravascular volume status of the patients in emergency services and intensive care units at diagnosis, treatment and follow-up stages is crucial yet pretty difficult. The purpose of hemodynamic monitoring is to determine cardiovascular insufficiency and to provide the most suitable treatment for unstable patients in critical condition (septic shock, hypovolemia, cardiogenic shock, etc.). Studies show that either of hypovolemia or volume overload may lead to serious clinical consequences including prolonged mechanical ventilation, higher mortality rates, renal dysfunction and disruption in oxygenation. ${ }^{[1]}$ Rivers et al. state that decrease in organ damages and increase in survival rates can be achieved in patients with serious sepsis and septic shock through target-specific treatment protocols including aggressive volume treatment aimed at central venous pressure (CVP) and physiological variables. ${ }^{[2]}$

Invasive and non-invasive methods are employed in order to determine the volume requirement in patients who applied to the emergency service. In clinical practice, the non-invasive methods such as physical examination (mental state, skin turgor pressure and skin drying, capillary refill time, mucous membrane hydration, temperature of the extremities, peripheral pulse palpation, heat rate and blood pressure, their orthostatic changes, urine volume), chest $x$-ray and laboratory parameters, and the invasive methods such as monitorization of cardiac output or central venous pressure are used in determining intravascular volume and directing the volume treatment. ${ }^{[3]}$

Emergency ultrasonography is also defined as Point of Care Ultrasound (POCUS). It is an imaging method that can be used by the physicians working in emergency services as well as radiologists and it is modified, limited to or focused on emergency conditions. After 1999, diagnostic ultrasound (USG) came into use in many hospitals providing emergency medicine education in USA, and more than $70 \%$ of these hospitals included USG training in their education program until 2001.[4,5] The first POCUS study was carried out by emergency physicians upon clinical use of echocardiography in an emergency service in $1988{ }^{[6]}$ In consequence of the studies which indicate that POCUS can be used for hemoperitoneum and hemopericardium in particular in trauma patients, focused abdominal sonography for trauma (FAST) came out. ${ }^{[7]}$ POCUS must be made in life-threatening cases such as abdominal aortic aneurysm, thoracoabdominal trauma, traumatic hemoperitoneum, pericardial tamponade, massive pulmonary embolism, tension pneumothorax, ruptured aortic aneurysm, cardiogenic shock and hypovolemia. ${ }^{[8]}$

In people with spontaneous breathing, intrathoracic pressure decreases during inspiration, the pressure difference between the right atrium and vena cava inferior $(\mathrm{VCl})$ increases, blood flow accelerates and causes VCl-diameter collapse. During expiration, the intrathoracic pressure rises again and the pressure difference between the right atrium and vena cava inferior decreases, leading to an increase in the diameter of the vena cava inferior. This respiratory variability in $\mathrm{VCl}$ diameter is known as the caval index (collapsibility index=VCImax$\mathrm{VClmin}$ /VClmax ) and is considered to reflect the intravascular volume state..$^{[9]}$ In mechanically ventilated patients, the increase in intrathoracic pressure during inspiration decreases the venous return gradient and the diameter of the vena cava inferior increases while its diameter decreases on expiration. This variability in the diameter of the vena cava inferior during mechanical ventilation(distensibility index=VCImax-VCImin / $\mathrm{VCImin}$ ) indicates the patient's response to fluid therapy ${ }^{[10]}$

In differential diagnosis of hypotensive patient, assessment of $\mathrm{VCl}$ collapsibility and distensibility is crucial in providing quick and proper treatment. It is important to decide if urgent volume replacement, vasopressor support, pericardiocentesis, thoracostomy, thrombolytic treatment, surgical examination or a combination of them is necessary for a hypotensive patient. The decision can be made by using POCUS in a fast and cheap way. ${ }^{\left[{ }^{[9]}\right.}$ Assessment of vena cava inferior diameter measurement, collapsibility and distensibility by using POCUS helps making the right volume replacement. It enables to prevent such complications as pulmonary edema, cerebral edema, electrolyte disturbances and dilutional coagulopathy that are caused by volume over-replacement. ${ }^{[1,12]}$

The purpose of this study is to compare $\mathrm{VCl}$ diameter, vena cava inferior- collapsibility index $(\mathrm{VCl}-\mathrm{Cl})$ and vena cava inferior- distensibility index (VCI-DI) measurement by POCUS to CVP value obtained by inserting invasive catheter in assessing the volume status and making the right volume replacement in emergency service and intensive care unit and to find the correlation between them. CVP measurement has lost popularity over time. However; being noninvasive, easy, cheap and repeatable makes POCUS indispensable for detecting and monitoring the volume status of critical patients in the emergency room and intensive care units. ${ }^{[9]}$ One aim of this study is to encourage emergency medicine and intensive care clinicians to use POCUS more frequently.

\section{MATERIAL AND METHOD}

The study was carried out prospectively on the patients above the age of 18 who applied to the Emergency Service Clinic between the dates $01.06 .2014-01.04 .2015$ or stayed in the emergency intensive care unit between these dates, and to whom central venous catheter was inserted for any indication upon obtaining the approval of Ondokuz Mayıs University Medical Faculty Clinical Research Ethics Committee dated 30.05.2015 (OMU CREC decree no: 2014/675). A total of 60 people, 26 women and 34 men, were included in this study. The patients were included in the study after necessary and adequate information on the study was given to the conscious patients themselves and the immediate relatives of the unconscious patients and their written consent was taken. 
The patients with cor pulmonale, pulmonary hypertension, severe tricuspid insufficiency, severe left heart failure $(E F<$ $40 \%)$, cardiac tamponade, and tension pneumothorax and those who are pregnant were excluded from the study. The patients from whom image cannot be taken due to intense gas superposition and obesity were also excluded from the study.

A data collection form was prepared in order to standardize data collection in the study. The data recorded on the form are as follows: name-surname, age, gender, systolic and diastolic tension arterial values, average arterial blood pressure, heart rate, respiratory rate of the patients, their admission diagnosis in application or emergency service intensive care unit, laboratory results (full blood count, electrolyte, kidney function tests, blood gas values) for CVP monitoring of the patients, respiration of the patients (spontaneous or mechanical ventilation), CVP measurement catheter type, CVP measurement values, $\mathrm{VCl}$ diameter measured by POCUS in expiration and inspiration, $\mathrm{VCl}-\mathrm{Cl}$ values, $\mathrm{VCl}-\mathrm{DI}$ values and three-month survival rates. $\mathrm{VCl}-\mathrm{Cl}$ and $\mathrm{VCl}-\mathrm{DI}$ were calculated using the formula below. ${ }^{[9,10]}$

\section{$\mathrm{VCl}-\mathrm{Cl}=$ (maximum $\mathrm{VCl}$ diameter-minimum $\mathrm{VCl}$ diameter)/ maximum $\mathrm{VCl}$ diameter $x 100$}

$\mathrm{VCl}-\mathrm{DI}=$ (maximum $\mathrm{VCl}$ diameter-minimum $\mathrm{VCl}$ diameter)/ minimum $\mathrm{VCl}$ diameter $\times 100$

Ultrasonographic imaging was performed at the bedside by the clinician certified for basic and advanced emergency ultrasonography by using Philips HD3 ultrasonography device according to american echocardiography association guidelines. Measurements; It was performed by only one clinician (Meltem Ince) in order not to affect the objectivity of the study. All measurements were made in supine position by a $3,5 \mathrm{mHz}$ sector probe. Vena cava inferior and aorta were detected by transverse examination using 3,5 MHz probe. Then, the probe was turned to the longitudinal plane on the vena cava inferior. On this plane, the heart was detected by cranial angulation first. Then, the junction point of hepatic veins with vena cava inferior was found by reducing the angulation. In the meantime, the liver was used as an acoustic window. In order to obtain optimal and standardized measurements in this position, measurements were taken in both inspiration and expiration phases by using $\mathrm{M}$ mode and directing the probe to $20 \mathrm{~mm}$ distal to the junction point of hepatic veins and vena cava inferior and they were recorded in millimeter

(Figure 1a, 1b). Simultaneous vital findings were obtained from the patients and simultaneous CVP measurements were made. CVP measurement was made on the reference point on the midaxillary line on a level with the fourth costal cartilage assuming the right atrium level as reference (zero) level. CVP measurement was made by trained emergency service and intensive care nurse by manometric devices and CVP results were recorded in $\mathrm{cm} \mathrm{H}_{2} \mathrm{O}$. Ultrasonographic $\mathrm{VCl}$ measurement was made by the ultrasound operator without knowing invasive CVP value of the patients measured centrally

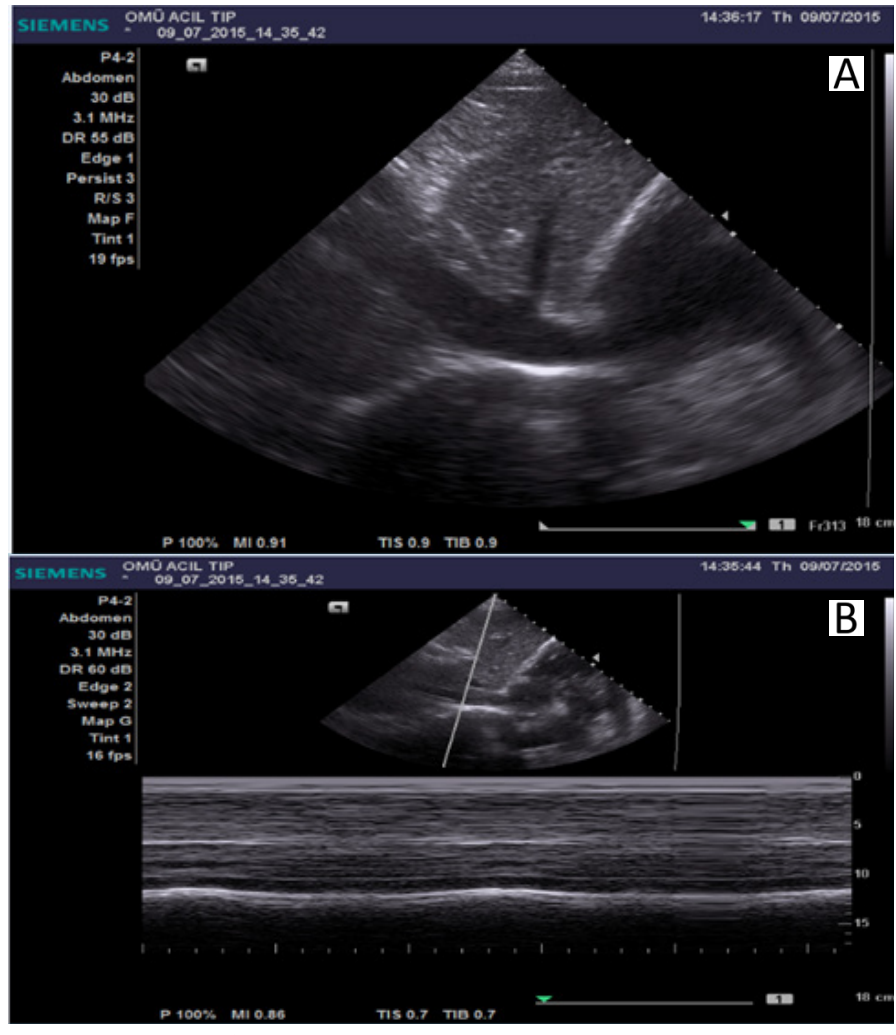

Figure 1. a) View of $\mathrm{VCl}$ in $\mathrm{B}$ mode in longitudinal section b) View of $\mathrm{VCl}$ in $\mathrm{M}$ mode in longitudinal section

The study data were uploaded to computer and assessed by means of SPSS (Statistical Package For Social Sciences For Windows v.18.0 SPSS Inc. Chicago, IL). Shapiro-Wilk test was made for test of normality of the data. In the table; the fact that the values on Assymp Sig. (significance) line are greater than 0.05 which is assumed as the limit value in statistical significance calculations indicates that distributions of the factors examined are normal, and the fact that they are smaller indicates that there isn't a normal distribution. Categorical measurements of the patients that participated in the study were summarized in numbers and percentages, and the numerical measurements are summarized as averages and standard deviation (median and minimum-maximum when necessary). The correlation between the continuous measurements is examined using spearman correlation coefficient.

\section{RESULTS}

Sixty patients were included in the study in total. $43.3 \%$ of the patients that participated in the study were female (n:26), $56.7 \%$ were male $(n: 34)$, and the mean age of the patients was $70.58 \pm 14.86$ (min: 21 , max: 93 ) years. When we examined diagnoses of the patients, we found that sepsis diagnosis was made at the most at the rate of $43.3 \%$, and it is followed by acute renal failure at the rate of $13.3 \%$, and gastrointestinal bleeding and aspiration pneumonia each at the rate of $8.3 \%$. Mean CVP value of the patients that participated in the study 
was $5.70 \pm(5.01) \mathrm{cmH} 2 \mathrm{O}$ (min: 0, max: 15). Mean value of $\mathrm{VCl}-\mathrm{e}$ diameter was $14.72 \pm(5.0) \mathrm{mm}$ ( $\min : 2$, max: 24$)$, mean value of VCl-i diameter was $9.1 \pm(5.9) \mathrm{mm}(\min : 2$, max: 21$)$, mean value of $\mathrm{VCl}-\mathrm{Cl}$ was $52.49 \% \pm(26.53)$ (min: 13 , max: 100), mean value of $\mathrm{VCl}-\mathrm{Dl}$ was $61.29 \% \pm(\min : 14$ max:100) (Table 1).

Table 1. Mean values of CVP, VCl-e diameter, $\mathrm{VCl}$-i diameter, $\mathrm{VCl}-\mathrm{Cl}$ and $\mathrm{VCl}$ DI of the patients

\begin{tabular}{lccccc} 
& $\begin{array}{c}\text { CVP } \\
(\mathbf{c m H 2})\end{array}$ & $\begin{array}{c}\text { VCl-e } \\
(\mathbf{m m})\end{array}$ & $\begin{array}{c}\mathbf{V C l}-\mathbf{i} \\
(\mathbf{m m})\end{array}$ & $\begin{array}{c}\mathbf{V C l}-\mathbf{C l} \\
(\mathbf{\%})\end{array}$ & $\begin{array}{c}\text { VCI-DI } \\
(\%)\end{array}$ \\
\hline N & 60 & 60 & 60 & 36 & 24 \\
Mean & 5.7 & 14.72 & 9.1 & 52.49 & 61.29 \\
Sd. & 5.01 & 5.00 & 5.90 & 26.53 & 31.35 \\
Min & .00 & 6.40 & 2.00 & 13.00 & 14 \\
Max & 15.00 & 24.40 & 21.00 & 100.00 & 100 \\
\hline
\end{tabular}

The study found that there is a weak positive correlation between systolic blood pressure, diastolic blood pressure, mean arterial pressure and CVP, and there is a weak negative correlation between heart rate and CVP. No correlation was found between respiratory rate and CVP (Table 2). In addition, the study also found that there is a weak negative correlation between systolic blood pressure, diastolic blood pressure, average arterial pressure, respiratory rate and $\mathrm{VCl}-\mathrm{Cl}$, and a weak positive correlation between heart rate and $\mathrm{VCl}-\mathrm{Cl}$ (Table 2).

\begin{tabular}{|c|c|c|c|}
\hline & & CVP & $\mathrm{VCl}-\mathrm{Cl}$ \\
\hline \multirow{3}{*}{ Heart Rate } & $\mathrm{R}$ & -.32 & ,39 \\
\hline & $P$ & .01 &, 002 \\
\hline & $\mathrm{N}$ & 60 & 60 \\
\hline \multirow{3}{*}{ Diastolic Blood Pressure } & $\mathrm{R}$ & .29 &,- 26 \\
\hline & $\mathrm{P}$ & .02 &, 04 \\
\hline & $\mathrm{N}$ & 60 & 60 \\
\hline \multirow{3}{*}{ Mean arterial pressure } & $\mathrm{R}$ & .28 &,- 27 \\
\hline & $P$ & .02 & ,03 \\
\hline & $\mathrm{N}$ & 60 & 60 \\
\hline \multirow{3}{*}{ Systolic Blood Pressure } & $\mathrm{R}$ & .24 &,- 26 \\
\hline & $P$ & .05 & 04 \\
\hline & $\mathrm{N}$ & 60 & 60 \\
\hline \multirow{3}{*}{ Respiratory Rate } & $\mathrm{R}$ & -.00 &,- 14 \\
\hline & $P$ & .96 &, 26 \\
\hline & $\mathrm{N}$ & 60 & 60 \\
\hline
\end{tabular}

The study found a positive correlation between CVP and VCl-e diameter, $\mathrm{VClO}-\mathrm{i}$ diameter, and a strong negative correlation between CVP and VCl-CI/VCI-DI (Table 3) (Figure 2,3,4,5).

Table 3. Correlation among CVP and VCl-e diameter, VCl-i diameter, CVI-Cl, VCI-DI

\begin{tabular}{lcccc} 
& $\begin{array}{c}\text { CVP and VCl-e } \\
\text { diameter }\end{array}$ & $\begin{array}{c}\text { CVP and VCI-i } \\
\text { diameter }\end{array}$ & $\begin{array}{c}\text { CVP and } \\
\text { VCI-Cl }\end{array}$ & $\begin{array}{c}\text { CVP and } \\
\text { VCI-DI }\end{array}$ \\
\hline $\mathrm{R}$ & .86 & .88 & -.81 & -.85 \\
$\mathrm{P}$ & .00 & .00 & .00 & 00 \\
$\mathrm{~N}$ & 60 & 60 & 36 & 24 \\
\hline
\end{tabular}

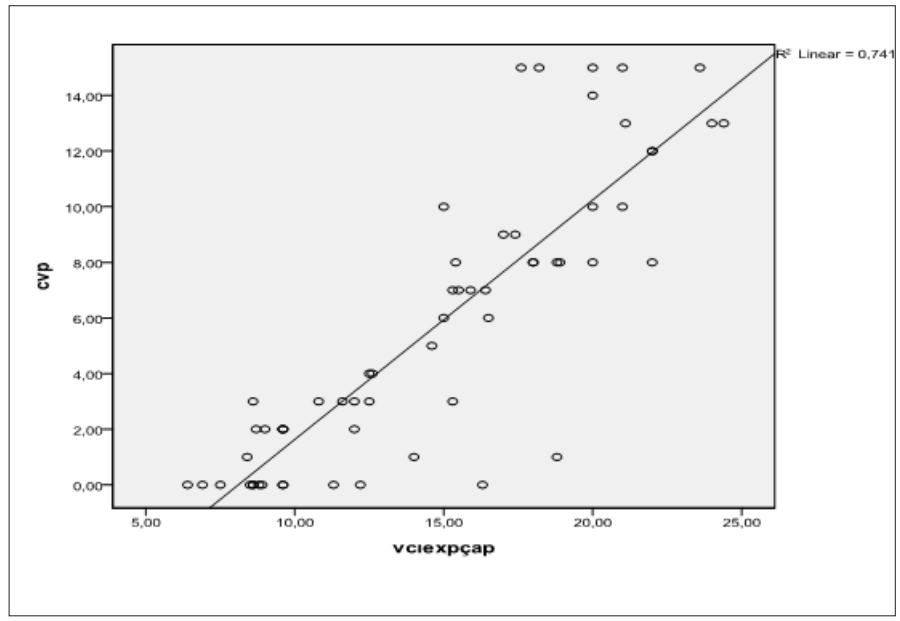

Figure 2. Chart of Correlation between CVP and VCl-e Diameter

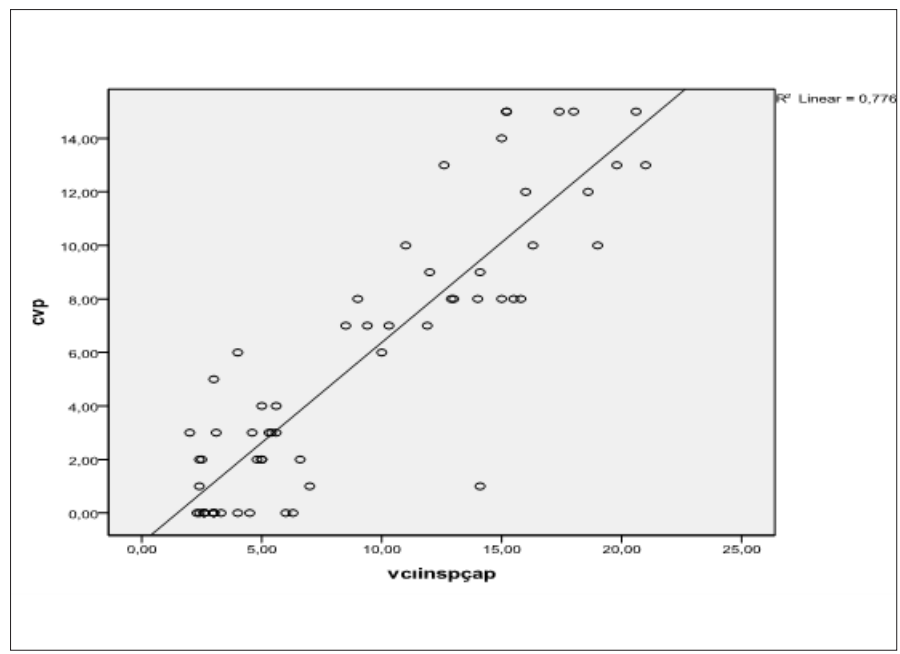

Figure 3. Chart of Correlation between CVP and VCi-i diameter

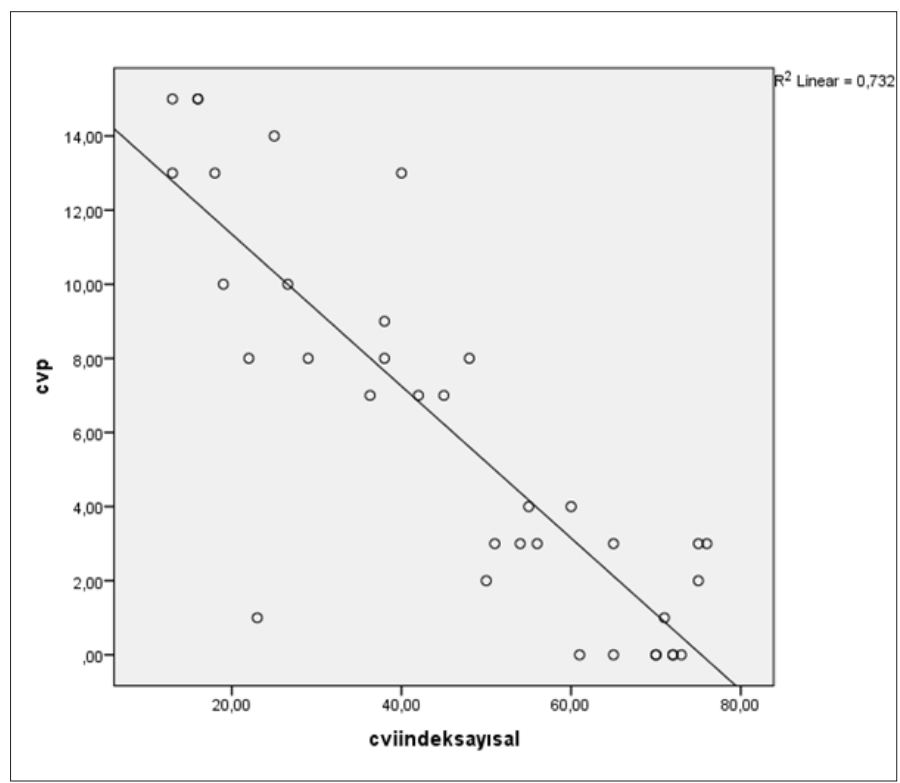

Figure 4. Chart of Correlation between CVP and $\mathrm{VCl}-\mathrm{Cl}$ 


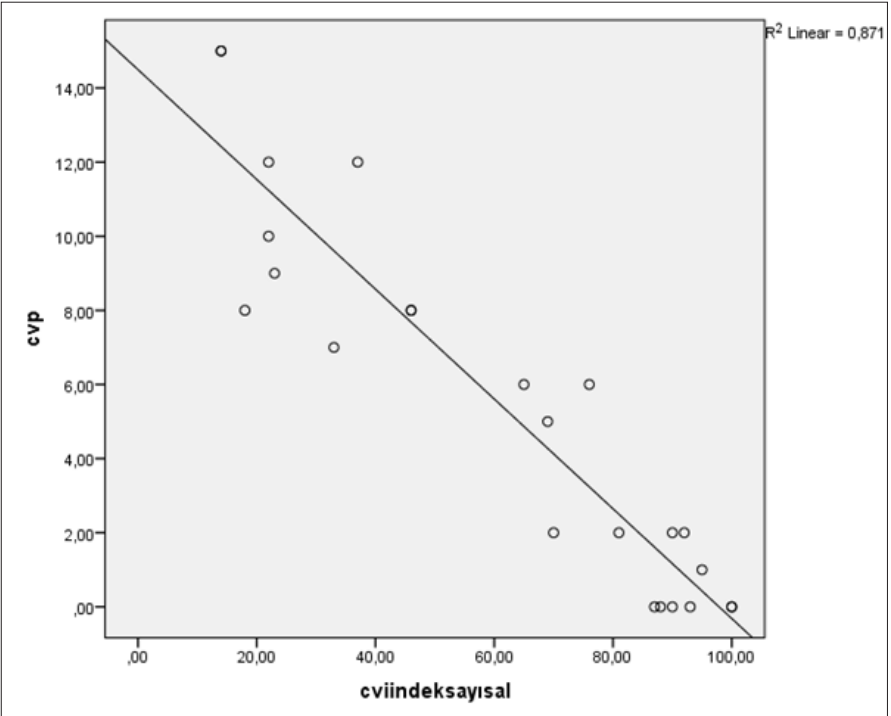

Figure 5. Chart of Correlation between CVP and VCI-DI

The study found that mean CVP value of the patients whose $\mathrm{VCl}-\mathrm{Cl}$ value is $20 \%$ and below (n:9) is $13.2(2.58) \mathrm{cmH} 2 \mathrm{O}$ (min: 8, max: 15); mean CVP value of those whose $\mathrm{VCl}-\mathrm{Cl}$ is below $50 \%(\mathrm{n}: 28)$ is 10.42 (2.989 $\mathrm{cmH} 2 \mathrm{O}$ (min: 7, max: 15); mean value of those whose $\mathrm{VCl}-\mathrm{Cl}$ is above $50 \%(\mathrm{n}: 32)$ is $1.78(1.869$ $\mathrm{cmH} 2 \mathrm{O}$ (min: 0, max: 6) (Table 4).

Table 4. Comparison of CVP values of the patients with $\mathrm{VCl}-\mathrm{Cl}$ above and below $50 \%$ and those below $20 \%$

\begin{tabular}{lccccc} 
CVP & N & Mean & Sd. & Min. & Max \\
\hline $\mathrm{VCl}-\mathrm{C}<\% 50$ & 28 & 10.42 & 2.98 & 7 & 15.00 \\
$\mathrm{VCl}-\mathrm{Cl}>\% 50$ & 32 & 1.78 & 1.86 & .00 & 6.00 \\
$\mathrm{VCl}-\mathrm{Cl}<\% 20$ & 9 & 13.22 & 2.58 & 8.00 & 15.00 \\
\hline
\end{tabular}

The study found that CVP measurement was made on 30 patients $(50 \%)$ to whom a central venous catheter was inserted through internal jugular vein (IJV) and the other 30 patients (50\%) to whom a central venous catheter was inserted through femoral vein (FV). The study also found that $\mathrm{VCl}-\mathrm{Cl}$ mean of the patients to whom central venous catheter was

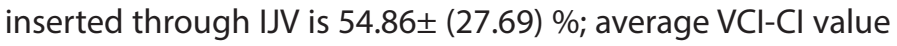
of the patients to whom the catheter was inserted through FV is $50.13 \pm(25.579 \%$. No significant difference is found among CVP and VCI diameters of the patients to whom central venous catheter was inserted through IJV and FV ( $p>0.05)$ (Table 5).

\begin{tabular}{|c|c|c|c|c|c|}
\hline & & $\mathbf{N}$ & $\%$ & Mean & $\mathbf{P}$ \\
\hline \multirow{2}{*}{ CVP } & IJV & 30 & 50 & $5.43 \pm 5.09$ & \multirow{2}{*}{.72} \\
\hline & FV & 30 & 50 & $5.96 \pm 4.96$ & \\
\hline \multirow{2}{*}{ VCl-e } & IJV & 30 & 50 & $14.72 \pm 5.14$ & \multirow{2}{*}{.95} \\
\hline & FV & 30 & 50 & $14.72 \pm 4.9$ & \\
\hline \multirow{2}{*}{ VCl-i } & IJV & 30 & 50 & $9.01 \pm 6.19$ & \multirow{2}{*}{.96} \\
\hline & FV & 30 & 50 & $9.19 \pm 5.69$ & \\
\hline
\end{tabular}

The study found that $60 \%$ of the patients that participated in the study have spontaneous respiration, and $40 \%$ receive mechanical ventilatory support. No significant difference was found in VCl-i, VCl-e diameter, VCl-Cl, VCI-DI and CVP between the two groups (Table 6).

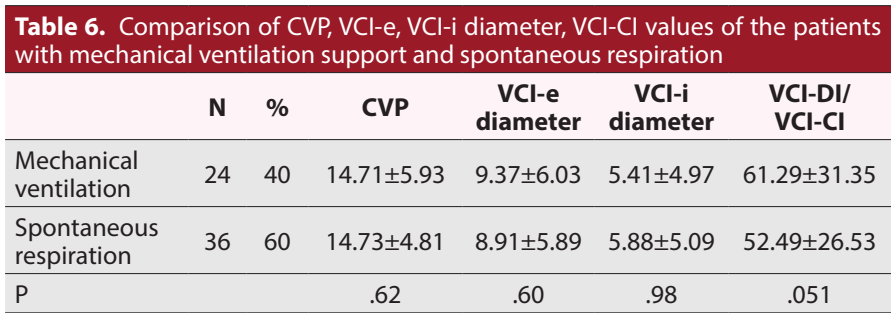

The study found that $38.3 \%$ of the patients that participated in the study were discharged with full recovery, and $61.7 \%$ died.

\section{DISCUSSION}

Volume treatment is crucial in treatment of the patients in critical condition and the patients with acute circulatory failure in particular. The purpose of volume resuscitation is to preserve sufficient tissue perfusion while avoiding any significant interstitial edema. Assessment of intravascular volume status in a timely, accurately and repeatable manner is important in adequate treatment of the critical patients. ${ }^{[12,14]}$ Hemodynamic dysfunction occurs in various clinical environments ranging from polyclinics to trauma-resuscitation areas. In addition, it can also occur in a wide range of clinical presentations ranging from mild systemic inflammatory response syndrome to advanced hemodynamic collapse and shock. For this reason, many researchers have carried out studies to develop reliable techniques or introduce biomarkers in order to foresee the volume response in the patients in critical condition. ${ }^{[13]}$ Therefore, it is crucial for clinicians to use POCUS which is quick, reliable and easy-to-use device in assessment of volume status of the patients in critical condition.

The reference point for assessing vascular volume status and heart preload in the patients in critical condition is monitorization of central venous pressure. CVP must certainly be monitored in cases that volume replacement must be made carefully such as shock and circulation failure, pediatric or cardiac diseases of the patients that apply to emergency service. ${ }^{[15]}$ However, CVP monitorization requires central venous catheterization by an invasive method which is often difficult in an urgent resuscitation and even impossible if the physician is inexperienced or in a countryside. ${ }^{[16]}$ POCUS is a technique that is often used in emergency services and intensive care units. It is even used in prehospital interventions and battlefields. POCUS is reliable, non-invasive and portable and images are easily interpreted by a broad range of specialists. Accurate measurements of internal organs and blood veins in particular can be made easily by POCUS. ${ }^{[1]}$ 
Vena cava inferior is the largest vein with the lowest pressure in the venous system. Vasodilation reflects the changes in venous pressure to a certain extent. These changes also reflect volume excess. Therefore, $\mathrm{VCl}$ diameter can be used as an important means of diagnosis in assessment of hypervolemia and volume status. ${ }^{[17,18]}$

Morishita et al. ${ }^{[19]}$ compared base deficit (Bee), lactate, circulating blood volume calculated by using pulse dye densitometry (PDD) which is a new method employed in detection of circulating blood volume to $\mathrm{VCl}-\mathrm{e}$, ANP and BNP in their study on healthy volunteers and hemodialysis patients; they stated that $\mathrm{VCl}$-e is more important than both ANP and BNP in detecting circulating blood volume in hemodialysis patients. In 2010, Akıllı et al. ${ }^{[20]}$ carried out a study on 50 volunteers and 28 sequential hemorrhagic shock patients and they that $\mathrm{VCl}$ diameter measured by POCUS is a stronger predictor value than other non-invasive indicators that are commonly used in estimation of shock index and acute hemorrhage such as blood pressure, pulse rate, serum lactate level and base deficit in hemorrhagic shock patients. In 2018, Sahalaby et al. ${ }^{[21]}$ carried out a study on 50 patients and they stated that there is a high correlation between VCl$\mathrm{Cl}, \mathrm{VCl}$ diameter max. and CVP. In 2017, Vaish et al. ${ }^{[22]}$ carried out a study on 50 patients staying in pediatric intensive care unit and stated that there is a positive correlation between $\mathrm{VCl}$ diameter and CVP, and a negative correlation between $\mathrm{VCl}$ diameter and $\mathrm{VCl}-\mathrm{Cl}$. Besides, they indicated in this study that effective volume treatment increases $\mathrm{VCl}$ diameter and decreases $\mathrm{VCl}-\mathrm{Cl}$. A recent study was conducted with 76 patients who were followed up for septic shock and were breathing under mechanical ventilation support. As a result of this study, it was reported that $\mathrm{VCl}-\mathrm{DI}$ value is a good predictor to evaluate fluid response in septic shock in mechanically ventilated patients. ${ }^{[23]}$ In literature, there are many similar studies indicating the correlation between ultrasonographic measurement of $\mathrm{VCl}$ and CVP. ${ }^{[16,24,25]}$ In this study, we found that there is a high positive correlation between CVP and $\mathrm{VCl}$-e diameter, $\mathrm{VCl}$-i diameter and high negative correlation between CVP with VCl-Cl and VCI-DI (Table 3) (Figure 2,3,4,5). Findings of this study are consistent with the literature.

Zhang et al. ${ }^{[1]}$ investigated the publications until May 2013 and reviewed 8 studies in total. All studies included critical patients, one study dealt with pediatric patients. There were 235 patients in total. Five studies included the patients receiving mechanical ventilatory support; two studies included the patients with spontaneous respiration; the remaining study didn't state the respiratory pattern. All these studies indicated that vena cava inferior measurements by POCUS is of great importance in estimating the volume response on particularly the patients receiving mechanical ventilatory support and the patients that were resuscitated with colloids. In their study Joerg C.Schefold et al. assessed the correlation between the sonographic changes in $\mathrm{VCl}$ diameter and the invasive hemodynamic changes in 30 patients who were diagnosed with sepsis and septic shock and monitored in mechanical ventilation support in intensive care unit and they indicated that sonographic measurement of $\mathrm{VCl}$ is correlated to CVP and other invasive parameters in assessment of volume status in the patients receiving mechanical ventilatory support. ${ }^{[26]}$ In this study, we found that $60 \%$ of the patients that participated in the study have spontaneous respiration, $40 \%$ of them receive mechanical ventilatory support and there is not any significant difference in $\mathrm{VCl}-\mathrm{i}, \mathrm{VCl}$-e diameter, $\mathrm{VCl}-\mathrm{Cl}, \mathrm{VCl}-\mathrm{DI}$ and CVP values between the two groups (Table 6). In consequence of the literature and this study, one can say that mechanical ventilation doesn't pose an obstacle for measuring $\mathrm{VCl}$ and $\mathrm{VCl}-\mathrm{Cl}$ by POCUS in detecting volume deficit of patients and assessing the response to the volume treatment.

Pacheco Sda et al. ${ }^{[27]}$ indicated that there is a correlation between the CVP measured in 60 patients to whom central venous catheter was inserted through internal jugular vein or subclavian vein after heart surgery and the CVP measured at reference (zero) level on femoral central venous catheter of the same patients. Boone et al. ${ }^{[28]}$ indicated that measurement of CVP in 40 patients through femoral veins is sufficient as much as the measurement of CVP through IJV and subclavian vein in the postoperative patients. This study found that CVP measurement was made on 30 patients (50\%) to whom a central venous catheter was inserted through IJV and the other 30 patients (50\%) to whom a central venous catheter was inserted through FV. CVP mean of the patients to whom central venous catheter was inserted through IJV was 5.43 $\pm(5.09)$; mean CVP value of the patients that were

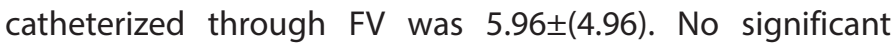
difference was found among CVP and VCl diameters in the patients to whom central venous catheter was inserted through IJV and FV ( $p>0.05)$ (Table 5). This study reveals findings that are consistent with the literature.

\section{Limitations}

FV catheterization is not recommended for CVP measurement. CVP measurement was made from $\mathrm{FV}$ in $50 \%$ of the patients in our research. This is one of the limitations of our study. However, in our study, no statistical difference was detected between the CVP values measured from FV and IJV.

\section{CONCLUSION}

Consequently, measurement of respiratory variability in $\mathrm{VCl}$ diameter by POCUS which is a rapid, reliable, easily applicable, cost-efficient and non-invasive method for the critical patients that have spontaneous respiration or receive mechanical ventilatory support in emergency services and intensive care units can be used in order to assess volume status and estimate CVP. In addition, we consider that the use of POCUS should be extended in emergency services and intensive care units where critical patients are monitored. 


\section{ETHICAL DECLARATIONS}

Ethics Committee Approval: The study was carried out with the permission of Ondokuz Mayıs University Medical Faculty Clinical Research Ethics Committee dated 30.05.2015 (OMU CREC decree no: 2014/675).

Informed Consent: All patients signed the free and informed consent form.

Referee Evaluation Process: Externally peer-reviewed.

Conflict of Interest Statement: The authors have no conflicts of interest to declare.

Financial Disclosure: The authors declared that this study has received no financial support.

Author Contributions: All of the authors declare that they have all participated in the design, execution, and analysis of the paper, and that they have approved the final version.

\section{REFERENCES}

1. Zang Z, Xu X, SYe, L Xu. Ultrasonographic measurement of the respiratory variation in the inferior vena cava diameter is predictive of volume responsiveness in critically ill patients:systematic review and metaanalysis. Ultrasaound Med Biol 2014;40(5):845-56.

2. Rivers E, Nguyen B, Havstad $S$, et al. Early goal-directed therapy in the treatment of severe sepsis and septic shock. N Engl J Med 2001;345(19):368-77.

3. Duane PG, Colice GL. Impact of noninvasive studies to distinguish volume overload from ARDS in acutely ill patients with pulmonary edema:analysis of the medical literature from 1966 to 1998. Chest 2000;118(6):1709-17.

4. Mateer J, Plummer D, Heller $M$, et al. Model curriculum for physician training in emergency ultrasonography. Ann Emer Med 1994;23:95-102.

5. Plummer D. Whose turf is it, anyway? Diagnostic ultrasonography in the emergency department. Acad Emerg Med 2007;7:186-187.

6. Mayron R, Gaudio FE, Plummer D, Asinger R, Elsperger J. Echocardiography performed by emergency physicians:Impact on diagnosis and therapy. Ann Emerg Med 1988;17:150-4.

7. Kendall JL, Hoffenberg SR, Smith S. History of emergency and critical care ultrasound:The evolution of a new image paradigm. Crit Care Med 2007;35:126-30.

8. Prof. Dr. Şefik Güney. Kolaylaştırılmış acil ultrason. Maltepe Üniversitesi Radyoloji A.B.D. 1.Edition;2010.

9. Kicher BJ, Himelman RB, Schiller NB. Noninvasive estimation of right atrial pressure from the inspiratory collapse of the inferior vena cava. Am J Cardiol 1990;66:493-6.

10. Barbier C, LoubieresY, Schmit C, Hayon J, Ricome J-L, Jardin F,et all. Respiratory changes in inferior vena cava diamater are helpful in predicting fluid responsiveness in ventilated septic patients. İntensive Care Med 2004;30(9):1740-6

11. Wiedemann HP, Wheeler AP, Bernard GR, et al. National Heart, Lung, and Blood Institute Acute Respiratory Distress Synndrome(ARDS)Clincal Trials Network, Comparison of two volume-management strategies in acute lung injury. N Engl J Med 2006;354(24):2564-75.

12. Levitov A, Mayo PH, Slonim AD. Critical Care Ultrasonography. 1 st ed. New York, NY:McGraw-Hill Medical;2009.

13. Van den Berg PCM, Jansen JRC, Pinsky MR. Effect of positive pressure on venous return in volume-loaded cardiac surgical patients. J Appl Physiol 2002;1223-31.

14. Saks V, Dzeja P, Schlattner U, Vandelin M, Terzic A, Wallimann T. Cardiac system bioenergetics:Metabolic basis of the Frank-Starling law. J Physiol 2006;571:253-73.

15. Pellerito Polak, Introduction to vasculer ultrasonography, 6 th edition; 2012.
16. Lorenzo RA, Morris MJ, Williams JB, et al. Does a simple bedside sonographic measurement of the inferior vena cava correlate to central venous pressure? The Journal of Emergency Medicine 2012;42(4):429-36.

17. Acosta JH. Hypertension in cronic renal disease. Kidney Int 1982;22:702.

18. Cantin M, Thibault $G$, Haile-Mesken H. Atrial natriuretic factor in the impuls conduction system of the heart. Trans Assoc Am physicions 1988;100-3.

19. Morishita Y, Ando Y, Ishii E, Arisaka M, Kusano E. Comparison of markers of circulating blood volume in hemodialysis patients. Clin Exp Nephrol 2005;9:233-7.

20. Akıllı B, Bayır A, Kara F, Ak A, Cander B. Inferior vena cava diameter as a marker of early hemorrhagic shock:a comparative study. Ulus Travma Acil Cerrahi Derg 2010;16(2):113-8.

21. Shalaby MIM, Roshdy HM, Elmahdy WM, Mezayen AEF. Correlation between Central Venous Pressure and the Diameter of Inferior Vena Cava by using Ultrasonography for the Assessment of the Volume Status in Intensive Care Unit Patients. The Egyptian Journal of Hospital Medicine 2018;72(10):5375-84.

22. Vaish H, Kumar V, Anand R, Chhapola V, Kanwal SK. The Correlation Between Inferior Vena Cava Diameter Measured by Ultrasonography and Central Venous Pressure. Indian J Pediatr 2017;84(10):757-62.

23. Fayed AM, Abd El Hady WS, El Aleem Abd El Hady MA, El Amir Melika M. Stroke volume variation compared with inferior vena cava distensibility for prediction of fluid responsiveness in mechanically ventilated patients with septic shock. Research and Opinion in Anesthesia \& Intensive Care 2020;7:84-90

24. Donahue SP, Wood JP, Patel BM, Quinn JV. Correlation of sonographic measurement of the internal juguler vein with central venous pressure. American Journal of Medicine 2009;27:851-5.

25. Aydın F, Uzun Y, Mocan MZ, H. Mocan, Topkara K. Hemodiyaliz Hastalarında Vena Cava İnferior Çapının Klinik Önemi. Omü Tıp Dergisi 1992;9(1):16-9.

26. Shefold JC, Storm C, Bercker S, et al. Inferior vena cava diameter correlates with invasive hemodynamic measures in mechanically ventilated intensive care patient with sepsis. The Jour of Emerg Med. 2010;38(5):6327.

27. Pacheco SS, Machado MN, Amorim RC, et al. Central venous pressure in femoral catheter; correlation with superior approach after heart surgery. Rev Bras Cir Cardiovasc 2008;23(4):488-93.

28. Boone BA, Kirk KA, Tucker N, Gunn S, Forsythe R. Iliac Venous Pressure Estimates Central Venous Pressure After Laporotomy. J Surg Res 2014;191(1): 203-7. 